\title{
MULTIVARIABLE MIXED MEANS AND INEQUALITIES OF HARDY AND LEVIN-COCHRAN-LEE TYPE
}

\author{
ALEKSANDRA ČIŽMEŠIJA AND JOSIP PEČARIĆ
}

Abstract. We consider integral power means of arbitrary real order, taken over cells in $\mathbf{R}^{n}$, and their dual means. We establish related mixed-means inequalities and then apply obtained results to derive multivariable analogues and some new generalizations of Hardy and Levin-CochranLee type inequalities. Moreover, we prove the constant factors involved in the right-hand sides of these relations to be the best possible, that is, they cannot be replaced with smaller constants.

Mathematics subject classification (2000): Primary 26D10, $26 \mathrm{D} 15$.

Key words and phrases: Mixed means, Hardy's inequality, Levin-Cochran-Lee inequality.

\section{REFERENCES}

[1] P. S. Bullen, Inequalities due to T. S. Nanjundiah, from Milovanović, G. V. (ed.) Recent progress in inequalities. Dedicated to Prof. Dragoslav S. Mitrinović, Kluwer Academic Publishers, 1998, 203-211.

[2] J. A. Cochran AND C.-S. LEE, Inequalities related to Hardy's and Heinig's, Math. Proc. Cambridge Phil. Soc. 96 (1984), 1-7.

[3] A. ČIŽMEŠIJA AND J. PEČARIĆ, Mixed means and Hardy's inequality, Math. Inequal. Appl. 1, No. 4 (1998), 491-506.

[4] A. ČIŽMEŠIJA, J. PEČARIĆ AND I. PERIĆ, Mixed means and inequalities of Hardy and Levin-Cochran-Lee type for multidimensional balls, Proc. Amer. Math. Soc. 128, No. 9 (2000), 2543-2552.

[5] A. ČIŽMEŠIJA AND J. PEČARIĆ, Somenew generalisations of inequalities of Hardy and Levin-Cochran-Lee, Bull. Austral. Math. Soc. 63 (2001), 105-113.

[6] A. ČIŽMEŠIJA AND J. PEČARIĆ, New generalizations of inequalities of Hardy and Levin-Cochran-Lee type for multidimensional balls, to appear in Math. Inequal. Appl.

[7] G. HaRdy, J. E. LitTLEWOOd AND G. Pólya, Inequalities, second edition, Cambridge University Press, Cambridge, 1967.

[8] F. Holland, On a mixed arithmetic-mean, geometric-mean inequality, Mathematics Competitions 5 (1992), 60-64.

[9] K. KeDlaya, Proof of a Mixed Arithmetic-Mean, Geometric-Mean Inequality, Amer. Math. Monthly, 101 (1994), 355-357.

[10] K. KedlayA, A Weighted Mixed-Mean Inequality, Amer. Math. Monthly, 106 (1999), 355-358.

[11] V. LEVIN, O neravenstvah III: Neravenstva, vypolnjaemie geometričeskim srednim neotricatel'noi funkcii, Math. Sbornik 446 (1938), 325-331.

[12] E. R. Love, Inequalities related to those of Hardy and of Cochran and Lee, Math. Proc. Cambridge Phil. Soc. 99 (1986), 395-408.

[13] T. MatsudA, An Inductive Proof of a Mixed Arithmetic-Geometric Mean Inequality, Amer. Math. Monthly 102 (1995), 634-637.

[14] D. S. MitrinoviĆ, J. E. PeČARIĆ AND A. M. FinK, Inequalities Involving Functions and Their Integrals and Derivatives, Kluwer Academic Publishers, 1991.

[15] B. Mond And J. PeČARIĆ, A Mixed means Inequality, Austral. Math. Soc. Gazette, 23 (1996), No. 2, $67-70$.

[16] B. MOND AND J. PeČARIĆ, A Mixed Arithmetic-Mean-Harmonic-Mean Matrix Inequality, Linear Algebra Appl. 237/238 (1996), 449-454. 
[17] B. MOND AND J. PEČARIĆ, Mixed means inequalities for positive linear operators, Austral. Math. Soc. Gazette, 23 (1996), No. 5, 198-200.

[18] B. G. PACHPATTE, On Hardy Type Integral Inequalities, Tamkang Journal of Math. 18, No. 2 (1987), $27-41$.

[19] B. G. PAChPATTE, On Multivariate Hardy Type Inequalities, Analele Stiintifice ale Univ. "AL. I. CUZA" Iasi, Tom. XXXVIII, s.I.a, Matem., 1992, f. 3., 355-361.

[20] C. D. TARNAVAS AND D. D. TARNAVAS, An inequality for mixed power means, Math. Inequal. Appl. 2, No. 2 (1999), 175-181. 